\begin{tabular}{lrr} 
N. $^{\circ} 104$ & Outubro-Dezembro & 1975 \\
\hline Volume LII - REVISTA DE HISTÓRIA - Ano XXVI
\end{tabular}

\title{
ARTIG0S
}

\section{CONSTANTINO E O IMPÉRIO CRISTÃO}

\author{
MARIA LUIZA CORASSIN \\ do Departamento de História da Faculdade de Filo- \\ sofia, Letras e Ciências Humanas da Universidade \\ de São Paulo.
}

\section{INTRODUÇÃO.}

A abdicação de Diocleciano foi seguida por um longo período de lutas civis, em meio às quais o sistema de tetrarquia foi abandonado.

Iniciamos a nossa exposição pelo estudo das linhas gerais dessa crise política, que se desenvolveu de 305 a 325, e durante a qual Constantino refez, em seu benefício, a unidade do poder, procurando torna-lo propriedade hereditária de sua dinastia.

Sua política opôs-se à de Diocleciano tambem em outro ponto de importância muito maior: o imperador aderiu ao cristianismo, que não somente cessou de ser perseguido, como ainda tornou-se a religião privilegiada e, de certa maneira, oficial.

Tornando-se cristão, o imperador não permitiu mais que o adorassem como um deus. Considerava-se, contudo, acima do comum da humanidade. A etiqueta da corte não chegou a ser modificada. A representação simbólica do imperador o foi ligeiramene. Ele não é mais representado como a encarnação do Deus-Sol, mas uma auréola de santo circundará doravante a sua cabeça. Será qualificado como "semelhante aos apóstolos".

Pela cristianização do Império, o reinado de Constantino marcou verdadeiramente uma nova era. Cristianizando-o, transformou-o pro- 
fundamente. Outro ato seu de grande consequência para o futuro foi a fundação de uma nova capital, rival de Roma.

Constantino foi, portanto, o autor de duas inovações essenciais: a mudança da política romana em relação ao cristianismo e a fundação de Constantinopla .

Esses dois aspectos constituirão as outras partes do trabalho, em seguida ao estudo das lutas civis. Deixamos de lado os demais aspectos de seu governo, pois em assuntos administrativos a obra de Constantino foi um prolongamento da de Diocleciano; inspirando-se no mesmo espírito, ele consolidou o absolutismo imperial e acabou de organizar a hierarquia composta por numerosos funcionários que formavam os quadros burocráticos do Estado romano.

Concentramos nossa atenção naquilo que nos pareceu mais originai e inovador em seu reinado, uma vez que Constantino foi o fundador do império cristão e oriental: colocou o cristianismo em condições de triunfar e o Império em situação de dividir-se em duas partes, oriental e ocidental, diferentes e desiguais.

A obra de transformação do Império de magistraturas em monarquia, projetada por Aureliano, empreendida por Diocleciano, prosseguiu e foi concluida por Constantino.

Por ocasião de sua morte, a constituição da monarquia estava praticamente concluida. Constantino conseguiu restabelecer em proveito próprio a unidade do Império, perdida desde 285 e implantar o princípio da hereditariedade dinástica; esse princípio foi levado às últimas consequências, uma vez que, quando de sua morte, Constantino partilhou o império entre seus três filhos e dois sobrinhos, à maneira merovíngia .

Efetivamente, muito mais que Diocleciano, Constantino foi um revolucionário, novator turbatorque rerum, como o viram os seus contemporâneos, os seus inimigos e principalmente os pagãos.

\section{$* \quad *$ \\ O FIM DA TETRARQUIA E A GUERRA CIVIL.}

O imperador Diocleciano procurou solucionar o problema criado pelos dois males mais graves que afligiam o mundo romano: a incessante repetição dos assaltos à fronteira pelos bárbaros e o ruinoso suceder-se no trono de imperadores eleitos de modo anárquico, forçados a esgotar as já insuficientes forças militares do império em deletérias guerras internas. Esses dois aspectos eram de tal modo correlacionados 
que frequentemente uma vitoriosa guerra empreendida na defesa da fronteira tornava-se causa de um mal maior, pois o general vencedor era elevado à dignidade de imperador, por seus soldados, obrigado a aceita-la com um punhal no pescoço e conduzido a uma guerra civil .

Uma eficaz proteção das fronteiras longíquas poderia ser alcançada, contudo, sem se transformar em título para justificar uma usurpação, sem provocar o aparecimento da figura de um pretendente. $O$ ideal seria que o imperador sempre obtivesse sozinho a vitória; mas, dada a vastidão do império, era impossivel que ele estivesse presente em todos os lugares; era imprescindivel subdividir a tarefa.

Diocleciano possuia um amigo devotado, de origem tão humilde quanto a sua e cuja ascensão devera-se à guerra; mais jovem e mais inculto que ele, civilitatis penitus expers, diz Eutrópio, irriquieto e violento de carater, mas bom soldado (1). Chamava-se Marco Aurélio Valério Maximiano. Diocleciano nomeou-o Cesar, ou seja, indicou-o para o trono, confiou-lhe o governo e a defesa das províncias ocidentais. No ano seguinte, em 286, promoveu-o a Augusto, portanto igual a si próprio em poder e dignidade, apenas inferior por ser menos antigo no cargo.

Mesmo dois imperadores eram insuficientes para a tarefa de dar proteção às amplas e sempre ameaçadas fronteiras. Alem disso, não fora resolvido o dificil problema de encontrar uma regra constante para regulamentar a sucessão ao trono, de modo a eliminar o perigo das usurpações e das habituais lutas intestinas que se seguiam.

A medida seguinte foi tomada alguns anos após e devia parecer definitiva ao espírito ordenado e esquemático de Diocleciano. Foram nomeados dois Césares, subordinados aos dois Augustos e destinados a sucede-los; devido aos poderes já atribuidos aos Césares, a sucessão tornava-se automática. Os Césares ao se tornarem Augustos escolhiam outros dois Césares; não restaria possibilidade de outro tipo de eleição e essa escolha asseguraria a ascensão dos melhores, sem os problemas de uma sucessão familiar, isto é, como fora nos felizes tempos dos Antoninos. O sistema era reforçado por um parentesco fictício que se criava entre os quatro, considerando-se irmãos os dois Augustos, e seus filhos adotivos, os dois Césares. A unidade do Estado não seria afetada porque acima de todos devia sempre prevalecer a autoridade do senior Augustus, o mais antigo dos Augustos. Foi invocada também uma sanção religiosa para determinar a subordinação que ligava o segundo Augusto ao primeiro: Diocleciano assumiu o título de Iovius e concedeu a Maximiano o de Herculius; portanto Diocleciano repre-

(1). - Apud Paribeni (R), Da Diocleziano alla caduta dell'Impero d'Occidente. Bologna, Licinio Cappelli, 1941, p. 19. 
sentava na terra a mente divina regente do mundo e Maximiano o potente braço do heroi, executor dos desígnios celestes.

Os dois Césares foram nomeados sete anos após a designação de Maximiano; os escolhidos foram Caio Galério Valério Maximiano, que se tornou César de Diocleciano e Marco Flávio Valério Constâncio, colocado sob as ordens de Maximiano e a quem mais tarde os escritores atribuiram o sobrenome de Cloro.

A reforma empreendida por Docleciano era das mais radicais. O império deixava de ser uma espécie de magistratura extraordinária e eletiva, como era considerado até então, tornando-se um tipo de colégio ao qual se ascendia por cooptação.

Os dois grandes eleitores existentes até então, o senado e o exército, foram totalmente eliminados do processo e uma vez que ambos agiam na qualidade de representantes do povo romano, esse mesmo povo deixava de ser o senhor daquele Estado, que no entanto continuava a chamar-se res publica Romanorum.

O império adquiriu uma fisionomia totalmente diferente daquela que the fora dado pelo seu fundador. A inovação fundamental do sistema da chamada tetrarquia, com a escolha de dois Césares por parte de dois Augustos e com a automática sucessão daqueles a estes, não conseguiria evitar ou diminuir o perigo da usurpação. $O$ aspecto mais importante é que a dignidade até então vista e imaginada como uma magistratura extraordinária e que por tanto tempo permanecera sem uma regra constante de sucessão, tornava-se uma instituição estavel e permanente.

O problema da estrutura jurídico-política do império tem sido insistente e agudamente estudado por juristas e historiadores. Em certos trabalhos, especialmente dos estudiosos italianos( De Franscisci, De Martino, Riccobono iunior, Alföldi) parece prevalecer a tese de que já o principado de Augusto é uma verdadeira monarquia adaptada à forma republicana e que já o próprio Augusto, embora aparentemente só aceitasse por um período limitado de tempo o imperium proconsulare extraordinário, fazendo renovar anualmente a sua tribunicia potestas, encarava o império como instituição permanente. Para tal fim deveria servir a espécie de cooptatio pela qual Augusto conferiu, primeiramente a Agrippa e depois a Tibério, poderes quase iguais ao seu, encontrando assim a maneira de assegurar a sucessão e perpetuar o regime monárquico. De qualquer modo, aquele expediente não foi mais usado a partir de Tibério e o reconhecimeno pelo senado repre- 
sentante do povo, como tambem a decisão do senado em favor da consecratio ou da damnatio memoriae do defundo imperador, devolveram o carater provisório e republicano à instituição imperial (2).

Com a tetrarquia de Diocleciano o senado que havia até então nomeado ou reconhecido o imperador, perdia tal faculdade entre suas prerrogativas.

Mudados radicalmente o conceito e a função da dignidade imperial, não havia mais razões para não assumir plenamente as manifestações exteriores próprias de um soberano absoluto, as quais já haviam começado a se infiltrar por tantas vias. O modelo foi fornecido pelo cerimonial das cortes orientais. O imperador não era mais o princeps, o primeiro entre os cidadãos, mas tornou-se definitivamente o senhor, o dominus, cujo correlativo, como bem observa Gibbon, é servus. Não mais existia a salutatio matutina do cidadão disciplinado e deferente ao príncipe, mas a prosternação e a adoração para aqueles raros súditos que eram admitidos ao insigne favor de poder ver o dominus et deus (3).

Diocleciano pode constatar muitos efeitos benéficos do sistema de governo por ele idealizado. Em 305 colocou em experiência a sua reforma mais essencial: a regulamentação da transmissão do poder imperial, que finalmente deveria seguir uma ordem constante, segura, imutavel. Seria interessante realizar a experiência em vida, não às vesperas da morte, a fim de poder verificar os efeitos.

Diocleciano, sempre coerente aos próprios princípios, teve a magnanimidade de renunciar ao imenso poder e a autoridade de impor ao seu colega Maximiano a mesma renúncia. A abnegação de Diocleciano não teve a merecida recompensa; ele viveu o bastante para ver a ruina e a subversão do que planejara.

A abdicação de Diocleciano e de Maximiano foi seguida por encarniçadas lutas civis.

A crise desencadeou-se com a abdicação dos Augustos a 19 de maio de 305. Diocleciano, num local próximo a Nicomédia, despojou-se de seu diadema, de seu cetro e de seu manto imperial, nomeando Galério para suceder-lhe; deu-lhe por Cesar um oficial dos protectores (4), Maximino Daia. No mesmo dia, em Milão, desenrolavase uma cena semelhante na qual Maximiano cedia seu trono a Constân-

(2). - Apud Paribeni, op. cit., p. 28, n० 1.

(3). - Paribeni, op. cit., p. 29.

(4). - Guarda pessoal do imperador. Vide Albertini (E.), L'empire

romain. 2. ed. Paris, Félix Alcan, 1936, p. 313 e p. 363. 
cio e colocava a púrpura dos Césares sobre os ombros de um outro oficial, Severo.

A escolha dos dois Césares que deveriam substituir os novos Augustos foi feita por Galério, ou mais provavelmente por Diocleciano de acordo com o seu ex-Cesar. Os escolhidos eram soldados: Maximino Daia e Flávio Severo, não apenas incultos e de baixa linhagem, mas devido a longa paz gozada pelo império nem mesmo eram enobrecidos por fitos militares.

Diocleciano acreditava haver regulamentado automaticamente a transmissão do poder, bem como a participação de cada um no poder. Constâncio, primeiro Cesar converteu-se em primeiro Augusto e Galério, segundo Cesar, em segundo Augusto. Foram substituidos em seguida por Severo e Maximino Daia, respectivamente, novos Césares e futuros Augustos.

A crise durará cerca de vinte anos até a vitória de Constantino contra Licínio em Crisópolis (18 de setembro de 324). A partir de 306 o sistema de tetrarquia foi destruido. De janeiro de 310 até o verão de 313 , a situação irá se aclarando pela eliminação sucessiva de Maximiano, Galério, Maxêncio e Maximino Daia. De 313 a 324 o Império ficou dividido entre Licínio e Constantino; este último trabalhou infatigaveimente para refazer a unidade do império.

Qual a origem de tal crise? Como se desenrolou essa guerra civil da qual resultará uma nova concepção de poder?

\footnotetext{
"Desde a fundação do Império Romano, Diocleciano é o único que por sua própria vontade desceu do ápice das honrarias e voltou à condição de simples cidadão. $E$ lhe aconteceu o que jamais ocorreu a alguem desde que existem os homens: morreu como simples particular e contudo foi incluido entre os deuses" (5).
}

Eutrópio escreveu estas palavras na época de Valente, mas seu assombro deve ter sido compartilhado pelos contemporâneos de Diocleciano. Ao abdicar, Diocleciano afirmou implicitamente a transcendência do poder imperial; este näo era inerente à pessoa que o exercia .

Uma vez que o poder imperial era transcendente, quem assegurava a sua permanência?

O povo romano? Esta seria a resposta na época do principado. O próprio Diocleciano contudo rejeitou esta resposta, pois abdicou por sua própria vontade e não pela do Senado (isto é, por deposição).

(5). - Eutrópio, 9, 27-28. Apud Rémondon (R.), La crisis del Imperio Romano. Barcelona, Labor, 1967, p. 59. 
O poder era recebido de Júpider que concedia a divindade? Seria a resposta dada pela mística da época; mas ela somente teria valor se em 305 ainda se acreditasse nos velhos deuses do Panteon romano.

Diocleciano colocou o problema do fundamento religioso do poder. Rejeitou as soluções apresentadas, mas não trouxe nenhuma resposta, por falta de uma doutrina.

A pessoa do imperador é divina e sagrada porque exerce o poder. Basta portanto apoderar-se do mesmo. Diocleciano deixou aberta a porta à anarquia, pois não especificou quais as qualidades necessárias para um homem ser investido no poder, nem de que forma a divindade escolhia e designava aquele a quem ela destinava tal poder.

Diocleciano procurou basear a autoridade imperial em três princípios: a divisão do império, a divindade dos imperadores e a escolha por cooptação. O seu sistema era mais complicado e refinado que uma monarquia asiática, baseada sobre os princípios dinásticos de hereditariedade e em certa medida, da unidade. O filho não seria por direito o sucessor de seu pai, mas o sucessor escolhido tornava-se, por adoção, filho de seu predecessor. Assim, na última divisão do império, Diocleciano excluiu do trono o filho de Constâncio Cloro, Constantino, e o fỉho de Maximiano, Maxêncio.

O sistema idealizado por Diocleciano não funcionou satisfatoriamente. Havia duas razões para que a tetrarquia constituida por Constâncio Cloro, Galério, Severo e Maximino Daia logo deixasse de funcionar normalmente.

A primeira era a antipatia recíproca entre Constâncio e Galério. Constâncio, provavelmente, como mais antigo, era citado antes de Galério nos atos oficiais; mas Galério, sucessor direto de Diocleciano, era o representante de Júpiter. Autoritário e violento, não se mostrava disposto a aceitar a precedência de Constâncio .

A segunda causa de atrito era a ambição do filho de Maximiano, Maxêncio (Marcus Aurelius Valerius Maxentius) e a do filho de Constâncio Cloro, Constantino (Caius Flavius Valerius Constantinus).

Não é improvavel, como foi dito acima, que a escolha dos Césares tenha sido providenciada pelo próprio Diocleciano que, rigidamente fiel ao seu esquema, teria desejado excluir propositadamente qualquer aspecto dinástico, escollhendo os seus sucessores fora das famílias dos governantes, utilizando o procedimento da adoção que levaria à eleição do melhor entre todos. Neste caso, porem, ao menos um dos descendentes diretos de um dos Augustos era muito superior aos dois escolhidos por adoção. Constantino, por suas qualidades e pela estima que gozava no exército tịnha razões para esperar um tratamento 
mais favoravel. Mais gravemente desiludido devia estar o descendente de Maximiano, Maxêncio. Constantino ao menos era filho de um dos Augustos, enquanto que Maxêncio, filho de um imperador demissionário, achava-se fora de qualquer participação no poder.

Ambos acreditavam-se qualificados para ocupar o cargo de Cesar e possuiam um círculo de amigos que encorajava estas pretensões. Ambos eram jovens, sobretudo Constantino: nascido de um primeiro casamento, talvez um concubinato de Constâncio Cloro com uma mulher do povo, Helena, ele devia ter apenas dezoito anos. Desde cedo iniciou-se nos negócios públicos e já gozava de popularidade entre os soldados.

O casamento de Maxêncio com a filha de Galério e o noivado de Constantino com Fausta, filha de Maximiano, pareciam aumentar as oportunidades dos dois jovens.

Não podemos afirmar que o sistema político idealizado por Diocleciano ter-se-ia mantido caso ele respeitasse os princípios dinásticos, mas é certo que as pretensões dos dois jovens apressaram o seu declínio.

Galério tomou a prudente medida de trazer Constantino para perto de si. Enviou-o a guerrear no Danúbio. No inlcio de 306, Constantino em uma rápida viagem que assemelhava-se a uma evasão, foi ao encontro de seu pai. Acompanhou-o à Bretanha, bem como a uma campanha no norte da ilha contra os Pictos e Escotos. Logo após, Constâncio, já doente quando do empreendimento dessa expedição, morreu em Eburacum a 25 de julho de 306.

As tropas da Bretanha e da Gália proclamaram Constantino como Augusto. Caso Galério aceitasse a escolha dos soldados voltar-seia aos tempos da anarquia militar. Ele não a confirmou, mas considerou necessário fazer uma concessão. Severo recebeu o grau de Augusto, ao qual a morte de Constâncio lhe dava direito; Constantino foi obrigado a contentar-se com o grau de Cesar.

Em Roma, Maxêncio invejava o sucesso de Constantino. A velha Roma encarava com mau humor a categoria de cidade provinciana na qual caira. A ausência da corte e do imperador feria ao mesmo tempo o orgulho e lesava os interesses da cidade. O Senado não dispunha mais de autoridade. Ao povo faltavam os grandes espetáculos e as vantagens dos tempos passados.

Os italianos estavam irritados com as recentes medidas que thes aplicavam os mesmos impostos que aos provinciais, mostrando-se propensos à revolta; as coortes pretorianas apresentavam tambem a mes- 
ma disposição porque a nova organização do exército tirava-lhe todo o prestígio e elas estavam sob ameaça de serem suprimidas.

Maxêncio com o apôio de todos estes descontentes fez-se proclamar princeps (28 de outubro de 306); em seguida, chamou Maximiano, que veio da Lucânia e retomou a posição de um Augusto em funç̧ão. Severo reuniu tropas no norte da Itália a fim de combater os usurpadores e aproximou-se de Roma. Muitos de seus soldados o abandonaram passando para o lado de Maximiano, seu antigo chefe. Severo, obrigado a retirar-se para Ravena, capitulou após um curto sítio. Após algum tempo, Maxêncio fe-lo executar, embora Maximiano houvesse prometido poupar-lhe a vida (307). Galério à frente de um exército tambem entrou na Itália a fim de restabelecer a ordem; temendo uma derrota, retirou-se logo da península.

Galério convidou o próprio Diocleciano para comparecer a Carnutum (na Panônia), esperando que seu conselho e sua autoridade trouxessem uma solução ao conflito que ameaçava desmembrar o império. Nem mesmo o criador da tetrarquia conseguiu todavia reorganiza-la. Se ele consentisse em retornar ao poder, provavelmente teria obtido êxito; mas ele não o desejava. Maximiano, que já se desentendera com o filho, e Galério, tentaram inutilmente persuadi-lo a retomar a púrpura imperial. A conferência de Carnutum decidiu apenas que um novo Augusto, antigo companheiro de Galério, Licínio (Valerius Licinianus Licinius) substituiria Severo (novembro de 307). Foi decidido ainda que Maximiano retornaria à vida privada e que Maxêncio seria excluido do Império.

A solução não foi satisfatória. Maxêncio manteve-se na Itália apesar da decisão de Carnutum, Maximiano não depôs a púrpura. Procurou aproximar-se de Constantino, fazendo-o desposar sua filha Fausta; queria o apôio que Maxêncio não lhe dera. A nomeação de Licínio criava novas dificuldades. Ele chegava ao primeiro posto do império sem passar pelo grau de Cesar, suplantando assim Maximino Daia e Constantino. Os dois Césares, por sua vez, protestaram. O primeiro fez-se proclamar Augusto pelas suas tropas e o segundo reclamou de Galério uma investidura semelhante. No início de 308 havia quatro Augustos, além de Maxêncio e Maximiano. Não havia entre os quatro Augustos nenhuma relação de subordinação. Todos os esforços de Diocleciano haviam se tornado estéreis pelas ambições rivais dos Augustos e Césares. A unidade do império estava quebrada. A incerteza do princípio de autoridade sobre o qual repousava o cargo supremo, esta doença mortal que desde Augusto atormentava o império, gerava uma nova crise que só terminaria após muito derramamento de sangue.

Dos competidores em luta, Maximiano foi o primeiro eliminado. Acusado de conspirar contra Constantino, foi morto ou obrigado a matar-se no início de 310. 
Em meio a estas desordens e intrigas, em 311, três dos quatro imperadores legítimos, Galério, Constantino e Licínio promulgam um edito suspendendo a perseguição ao cristianismo.

Galério morreu nesse ínterim, em maio de 311, após ter sido devorado durante mais de um ano por cruel moléstia, o que explica a sua atitude passiva em relação aos acontecimentos no Ocidente.

Após a morte de Galério. por eliminação, voltara-se a uma tetrarquia: Constantino, Maxêncio, Licínio e Maximino Daia. A evolução lógica terá prosseguimento. Constantino irá desembaraçar-se de Maxêncio em 312 e Licínio de Maximino em 313.

No Ocidente, Constantino e Maxêncio enfrentaram-se. O último combate deli-se em 28 de outubro de 312 em Rochas Rubras (Saxa Rubra) próximo a Ponte Múlvia, que atravessa o Tibre a algumas milhas de Roma. Maxêncio, completamente vencido, afogou-se no Tibre ao tentar fugir. Ao entrar triunfante em Roma, Constantino licenciou os pretorianos e fez reconhecer sua autoridade sem resistência pelas províncias que haviam apoiado Maxêncio: os italianos perceberam que era tão caro sustentar uma guerra civil quanto pagar impostos.

O desentendimento agravava-se agora entre Licínio e Constantino de um lado e Maximino de outro. Este continuava perseguindo os cristãos enquanto que Licínio e sobretudo Constantino seguiam uma política diferente. A brutalidade de Maximino tornava-o odioso a muitos de seus súditos. Foi ele que tomou a iniciativa de romper a convenção concluida após a morte de Galério: desejando expandir seus domínios às expensas de Licínio, atravessou o Bósforo e apoderou-se de Bizâncio. Licínio foi opor-se ao seu avanço. Os dois exércitos encontraram-se perto de Andrinopla. Maximino, derrotado numa batalha, fugiu para a Cilícia onde morreu no verão de 313 .

Havia um acordo aparente entre Licínio e Constantino. Foram feitos arranjos, tais como o casamento de Licínio com Constância, irmã de Constantino. A $1 .^{\circ}$ de março de 317 Constantino e Licínio proclamaram Césares a Crispus e Constantino-o-Jovem (ambos filhos de Constantino) e a Licínio-o-Jovem (filho de Licínio e de uma escrava, legitimado após seu nascimento). O mais velho dos três Césares, Crispus, tinha uma dezena de anos; assim, deixava-se de lado, ostensivamente, os princípios de Diocleciano. Substituia-se a cooptação pela hereditariedade. Ao mesmo tempo, a fim de fundamentar sua autoridade sobre um direito hereditário, Constantino fazia circular genealogias que ligavam Constâncio Cloro a Claúdio-o-Gótico. Desde 315 ele passa a chamar-se Constantino-o-Grande (Maximus).

Devido a este espírito dinástico, cada um dos dois Augustos desejava eliminar o outro e reservar todo o poder para si e para os seus. 
Ambas as partes esperavam o momento favoravel. A política religiosa, como ocorrera outrora com Maximino Daia, tornou-se outra causa da hostilidade entre os dois imperadores, pois Licínio perseguia os cristãos. Em 324 a luta abriu-se: o pretexto encontrado por Licínio foi a intrusão em suas províncias de tropas de Constantino, que haviam penetrado na Trácia para lutar contra os Godos. Licínio foi derrotado em Andrinópolis e Crisópolis. Refugiado na Nicomédia, foi cbrigado a render-se a Constantino; alguns meses mais tarde, este acusou-o de conspiração, fazendo-o matar. Licínio-o-Jovem tambem será executado mais tarde.

Desde 323, Constantino elevara a Cesar um seu terceiro filho, Constâncio, nascido de Fausta em 317. Agora Constantino era senhor único e absoluto, tendo a seu lado apenas herdeiros e não colegas.

A análise destes fatos mostra-nos que a luta civil originou-se porque o mecanismo de transmissão de poder criado vor Diocleciano teve seu funcionamento prejudicado pelo carater heterogêneo dos princípios em que se baseava:

- a cooptação dava direito aos Césares ae varticipar do poder e recolher a herança dos Augustos (após a morie de Constâncio, seu Cesar o sucedeu).

- a antiguidade da eleição fixava a ordem hierárquica (com a morte do primeiro Augusto, Constâncio, a 25 de julho de 306, Galério converteu-se em primeiro Augusto e Severo em segundo Augusto).

- os laços familiares (filiação adotiva de Severo por Constâncio, de Maximino por Galério; a entrada do Cesar na família de seu Augusto) reforçava a eleição (ou antes, a cooptação)

E importante observar que estes princípios são contraditórios. Por antiguidade, Constâncio era o primeiro Cesar, e portanto o primeiro Augusto, enquanto que por cooptação e filiação era apenas Herculius. Por meio da cooptação Licínio converteu-se automaticamente em segundo Augusto em 308, enquanto que apesar de sua antiguidade, Maximino Daia continuava sendo apenas Cesar. Este toi o motivo que o levou a proclamar-se Augusto. Surgiu assim um conflito entre a filiação adotiva e a filiação natural. Em 306 o exército de Constâncio mostrou sua preferência pela filiação natural (Constantino) em lugar da filiação adotiva (Severo).

O defeito do sistema consistia na mistura de duas regras incompatíveis. Uma, a da cooptação, ou seja, a eleição subjetiva e arbitrária por um homem. Outra, a do automatismo próprio do sistema dinástico (transmissão hereditária e primogenitura); esta era indiscutivel 
porque está alem de qualquer intervenção humana. Ora, Diocleciano fez esta automaticidade repousar na cooptação.

Seja pelo empirismo da reforma ou por sua falta de doutrina, Diccleciano não deixou firmado o fundamento do poder imperial e tampouco o seu exercício ou transmissão. Constantino, por sua vez, deu forma definitiva ao que estava paulatinamente se esboçando. Houve consolidação da tendência em conceder carater sagrado ao poder imperial, apesar deste sofrer um aparente declínio durante a anarquia militar.

Diocleciano marcou um retrocesso; o imperador não é um deus, ele apenas participa da divindade; o carisma é associado ao imperador e não ao homem que é imperador.

Este retrocesso - ou progresso - foi devido à evolução religiosa tanto cristã quanto pagã. Em Diocleciano era devido à tradição romana, fundamentando-se na transcendência da deusa Roma; o carater sagrado dos magistrados só se associa às suas pessoas porque estão investidas das magistraturas.

Constantino, do mesmo modo que Diocleciano, não considerava que seu carater divino estivesse ligado à sua pessoa; estava ligado ao seu poder imperial.

A origem divina do poder vai se delineando progressivamente. Constantino encontrou a origem divina do poder que conquistou no momento em que nas moedas, cunhadas em 330, aparece uma mão saida do céu, colocando-lhe o diadema. Sua autoridade lhe é dada por Deus. O fundamento do poder imperial foi encontrado.

Para que esta autoridade e este poder estabelecidos por Deus sejam reconhecidos como legítimos, é necessária a conversão do imperador e de seus súditos.

A máxima genialidade de Constantino talvez consista em haver realizado com êxito a síntese de sua ação política, a reunificação do império e a edificação da monarquia, e de sua atitude em relação ao cristianismo, calculando suas possibilidades de triunfo e agindo de forma que estas se transformassem em probabilidades.

"O acaso é que faz com que alguem se torne imperador. Mas é preciso agir de modo que aqueles a que a força do destino faz reinar sejam dignos do poder" (6).

(6). - História Augústea. Heliogábalo, 34, 4. Apud Rémondon, op. cit., p. 62 . 
Por mais duvidosa que seja sua atribuição a Constantino, essa frase expressa com exatidão a sua idéia.

Deus é quem escolhe os imperadores e não os homens, ainda que o faça através dos homens: a proclamação pelo senado ou pelo exército e a cooptação. Mas a solução mais simples, segura e menos discutivel é a herança dinástica, segundo a ordem cronológica dos nascimentos. Daí a proclamação como Césares de Crispo (n.303) e de Constantino-o-Jovem (n. 316); Constâncio (n. 317) tambem o é em 324; em 333, Constante (n. 320); em 335, é a vez de seu sobrinho Dalmácio. A única participação humana é que se procure fazer com que aqueles que são chamados por Deus para reinar sejam dignos disso: daí a educação que Constantino deu a seus filhos, fazendo deles uns

\section{"fanáticos que tremem por sua salvação" (7).}

Constantino ascendera ao trono em desrespeito às normas estabelecidas por Diocleciano; assistido por uma invariavel sorte durante toda sua vida, senhor inconteste de todo o mundo civilizado, que ele reconduzira à unidade e à segurança, criador de uma nova capital, convencido senão de sua própria divindade pelo menos de uma constante proteção divina, o imperador não cogitava em retomar a experiência diocleciana. Considerava seus filhos como os mais indicados continuadores de sua obra. Assim atenderia tambem à necessidade de subdividir a imensa massa do império e de entregar a defesa das fronteiras aos príncipes imperiais mais próximos a cada uma delas. $O$ vínculo familiar e a proteção divina manteriam o bom entendimento entre os cinco herdeiros, o que não sucedera aos tetrarcas nomeados por Diocleciano.

\section{CONSTANTINO E O CRISTIANISMO.}

Esta questão pode ser estudada sob três aspectos: a conversão de Constantino, a sua política em relação ao cristianismo e as suas intervenções em assuntos da Igreja .

A conversão deConstantino é um problema dificil e controvertido. Sem entrar em detalhes, é preciso observar que Constantino chegou ao cristianismo lentamente, que os progressos de sua conversão acompanham os de sua obra política e que os assuntos religiosos sempre o preocuparam.

Ele era pagão e adepto do culto solar, inicialmente. Em 310 teve uma visão num santuário de Vosgos: Apolo apareceu-lhe. Sua religiosidade e seu fervor em relação ao monoteismo solar aumentaram.

(7). - A. Piganiol. Apud Rémondon, loc. cit. 
Durante o reinado de Diocleciano o tratamento dispensado aos cristãos nas diferentes partes do império era desigual. Após sua abdicação essa desigualdade aumentou. Constâncio Cloro governava a Gália e a Bretanha, demonstrando tolerância em relação aos cristãos; quando a Espanha passou para seu poder, tambem se beneficiou dessa tolerância: as perseguições aos cristãos cessaram. Constantino demonstrou ainda mais abertamente que seu pai a sua simpatia em relação ao cristianismo. Severo, Licínio e Maxêncio não perseguiram os cristãos com zelo: a luta pelo poder os interessava mais que a perseguição religiosa. Mas esta continuava nas dioceses orientais, comandada por Galério e Maximino Daia; os mártires eram numerosos, principalmente nas províncias deste último.

A perseguição, pouco eficaz no Oriente e abandonada no Ocidente, não poderia continuar por muito tempo. A doença de Galério acabou por cansa-lo; de acordo com Constantino e Licínio, ele publicou em 311, poucos dias antes de sua morte, em edito autorizando os cristãos a praticar seu culto. Este edito nunca foi anulado; é portanto a partir deste momento que a existência do cristianismo foi oficialmente reconhecida e permitida. A era dos mártires estava finda.

Era necessário fazer executar o edito de Galério em todo o império, isto é, estender sua ação às províncias sob o controle de Maxêncio e Maximino. Maxêncio, desejoso de não ter contra si os cristãos da Itália concedeu-lhes voluntariamente os benefícios das novas medidas. Maximino, contudo, recebeu mal o edito de tolerância e reiniciou a perseguição antes do término de 311. Mandou matar o bispo de Alexandria, Pedro e o bispo de Emeso, Silvano. A fim de reforçar os cultos pagãos quis organiza-los sob a forma de uma hierarquia administrativa, semelhante à do clero cristão: em cada cidade um sacerdote principal devia ter autoridade sobre os demais; os sacerdotes principais das diferentes cidades teriam acima deles um grão-sacerdote, chefe do culto para toda a província; o sacerdócio assim disciplinado teria por tarefa essencial o combate ao cristianismo.

A política de Licínio e Constantino foi dirigida em sentido contrário. Durante a campanha contra Maxêncio, Constantino resolveu converter-se decididamente ao cristianismo e nele procurar um apôio ao seu poder.

Logo correu a versão que ele teria tomado esta resolução após uma visão miraculosa: uma cruz e a promessa de vitória teriam lhe aparecido no céu, alguns dias antes da batalha de Ponte Mílvia.

Constantino e Licínio, reunidos em Milão após a derrota de Maxêncio, no início de 313 , confirmaram e completaram o edito de 311 : a liberdade de culto concedida aos cristãos devia ser plena; os imó- 
veis que lhes haviam pertencido e que haviam sido confiscados deveriam ser restituidos. Igual liberdade era garantida a todas as religiões.

A queda de Maximino Daia assegurou a aplicação do edito na Ásia e no Egito. O ano de 313 foi o começo da "paz da Igreja": as perseguições terminavam com a vitória do cristianismo em toda a extensão do mundo romano. Houve uma retomada de perseguições nos anos seguintes, mas foi breve e localizada nas províncias de Licínio; este permanecera pagão e via nos cristãos partidários de Constantino, seu rival político.

A partir de 319 ou 320 os cristãos da Âsia e do Egito foram perseguidos por Licínio, que os expulsou de empregos públicos e do exército; sua polícia interditava as assembléias de culto e os concílios; os cristãos que protestaram foram condenados aos trabalhos forçados ou executados. Esses excessos terminaram após a vitória de Constantino sobre Licínio.

Os cristãos, por sua vez, beneficiaram-se do enfraquecimento do império, agitado por essa nova crise. $O$ cristianismo e o paganismo tornaram-se nas mãos dos imperadores rivais verdadeiras armas utilizadas na guerra civil. Ocupados em disputar o poder, teriam estes homens de Estado compreendido o verdadeiro significado, a amplitude $\mathrm{e}$ as consequências advindas a longo prazo de seus atos?

As considerações políticas podem ter levado Constantino a aproximar-se das comunidades cristấs instaladas nos domínios de seu rival enquanto sua evolução interior pode te-lo encaminhado para o cristianismo, pelo qual começou a inclinar-se decididamente a partir de 320 .

Os adversários do cristianismo foram impotentes contra a vontade declarada de Constantino. Por uma reviravolta total, o cristianispassou da proscrição a uma situação privilegiada sem que ninguem ousasse protestar com energia.

O fracasso das perseguições gerara em muitos a conviç̧ão de que perseverar na luta violenta contra o cristianismo seria inutil. Uma emoção simpática e respeitosa ligava-se à lembrança dos mártires. Alguns se perguntavam se o Deus dos cristãos não seria tão verdadeiro e mesmo mais poderoso do que as demais, pois seus fieis, tendo contra si as armas do Estado e a opinião da maioria, conseguiram resistir. As desgraças da época talvez fossem explicadas não pela cólera dos antigos deuses irritados com a impiedade dos cristãos, mas pela vingança do Deus dos cristãos, uma vez que seus devotos haviam sido maltratados. Seria mais prudente permitir o culto deste Deus temivel e seria mesmo aconselhavel participar dele.

Esses sentimentos são claramente expressos no edito de 311 , no qual Galério renegava sua anterior política. Constantino, por sua vez, 
estava convicto de que devia sua vitória ao Deus dos cristãos, do qual ele e seu pai, Constâncio Cloro, haviam merecido a proteção por sua abstenção em aplicar os editos de perseguição. Havia ainda o sentimento de que o paganismo estava esgotado, enquanto que o cristianismo apresentava-se rico em possibilidades, como uma força do futuro. Os acontecimentos haviam provado o engano dos imperadores quando julgaram ser do interesse do Estado a supressão do cristianismo. Ao contrário, esse interesse levaria os príncipes a favorecer os cristãos.

A fé pessoal de Constantino e a preocupação em fortalecer o império uniam-se para leva-lo a proteger o cristianismo, a enriquecer a Igreja e a aumentar a sua influência (8).

Constantino recebeu o batismo apenas algum tempo antes de sua morte. Tal fato pode ser explicado pelo costume de muitos catecúmenos: diminuir o mais possivel o intervalo entre o batismo, que apaga todas as faltas anteriores, e a morte; aumentavam assim as possibilidades de salvação. Muito antes de ser batizado, porem, Constantino já havia realmente se convertido e comportava-se já como cristão.

Constantino preocupou-se com a aplicação do edito que ordenava a restituição dos bens confiscados aos cristãos e pagava indenizações suplementares em muitos casos; os imóveis pertencentes às igrejas ficaram isentos de imposto predial e as igrejas tiveram a faculdade de receber legados. As liberalidades imperiais permitiram a construção de novos edifícios para o culto; o palácio de Latrão, que pertencia à mulher de Constantino foi doado ao bispo de Roma. Graças ao imperador e à sua mãe, Helena, santuários foram construidos na Palestina, na gruta de Belem onde Cristo nasceu, no local de sua cruz, no seu sepulcro, atraindo grande número de peregrinos.

O monograma formado pelas primeiras letras gregas de "Christos" passou a figurar nas moedas e nas inscrições oficiais.

Constantino, contudo, não rompeu com o paganismo oficial. A separação entre o paganismo e o Estado somente teve lugar em 379 . Continuou sendo o pontifex maximus, fundou Constantinopla segundo os ritos pagãos tradicionais, permitiu que os templos subsistissem e que novos templos fossem edificados. O culto imperial persistiu, reduzido praticamente a manifestações de lealdade e a festas laicizadas.

A política imperial contudo já tendia a se orientar para a perseguição ao paganismo. A consulta a advinhos e arúspices passou a ser permitida somente em determinados casos; vários templos da Ásia foram destruidos ou fechados; os funcionários passaram a ser escolhidos

(8). - Albertini, op. cit., p. 356. 
de preferência entre os cristãos. Nos próprios editos em que autorizava os pagãos a manterem sua religião, as referências a ela eram feitas em termos injuriosos e a liberdade de culto era apresentada como uma concessão provisória .

Constantino tambem não favoreceu expressamente o cristianismo. Limitou-se a modificar a legislação que prejudicava os cristãos, como a supressão das leis de Augusto sobre o celibato; legislou de modo que $o$ domingo foi santificado, colocado assim em igualdade com os dias de festa pagãos; autorizou a libertação dos escravos mediante uma declaração das igrejas. Ao reconhecer a arbitragem dos bispos com a mesma validez das sentenças dos tribunais civis, fundou a jurisdição episcopal.

O interesse de Constantino em relação à Igreja levou-o porém a interferir nos assuntos religiosos com o objetivo de manter entre os cristãos a unidade de disciplina e de dogma. O cristianismo tomou rapidamente um aspecto de religião de Estado, o que representava a vantagem de ter a seu lado a força governamental, mas o inconveniente de ocasionar a ingerência do poder temporal no domínio da fé.

\section{A FUNDAÇAOO DE CONSTANTINOPLA.}

Constantino, cristianizando o Império, transformou-o profundamente; outro ato seu que teve profundas consequências foi a fundação de uma nova capital.

O imperador venerava a antiguidade de Roma e procurou embeleza-la; não quis ficar em posição de inferioridade em relação a Maxêncio que havia construido um circo, decorado o Forum com estátuas e iniciado a construção, próximo ao Forum, de um templo e de uma basílica colossal. Constantino terminou a construção do templo e da basílica. Em 315 foi inaugurado o arco que comemora a sua vitória sobre Maxêncio e cuja decoração foi feita em grande parte com pedaços tirados de vários monumentos anteriores. Seu nome ficou ligado tambem a construção de vastas termas edificadas no Quirinal.

Muitos imperadores, antes dele, haviam deixado sua marca em Roma. Constantino desejava ligar sua memória às cidades que deveriam ser quase inteiramente obras suas. Cirta, reconstruida por ele das ruinas que a usurpação de Domício Alexandre (9) lhe havia acarretado,

(9). - O vigá-io da Āfrica, Lucius Domitius Alexander, aproveitou a desordem geral e fez-se proclamar imperador pelas tropas de sua diocese. Em 310 ou preferentemente em 311, o prefeito do pretório de Maxêncio, Rufus Volusianus, tomou a África de Domitius Alexander, o qual foi vencido e morto. A expedição foi conduzida com ferocidade; Cartago e principalmente Cirta sofreram pesados danos. 
foi chamada de Constantina. O mesmo nome foi tomado por Arles, onde Constantino permaneceu bastante tempo e abriu uma casa de cunhagem de moedas.

A sua grande criação porem foi Constantinopla, a "cidade de Constantino".

Por que Constantino fundou Constantinopla? Os historiadores alegam razões religiosas: como Deus o fez triunfar sobre Licínio, ele manifestou seu agradecimento

"mudando sua capital para longe daquela Roma infectada de um paganismo incuravel, para uma cidade inteiramente cristã" (10);

alegam ainda razões estratégicas (11), econômicas (12), e políticas (13).

No entanto, tudo foi feito para que a cidade de Constantinopla, a Nova Roma, fosse semelhante à Antiga. O problema consiste pois em descobrir porque foi criada uma Nova Roma e porque foi instalada em Bizâncio.

Por que fundar uma Nova Roma?

Desde o século III, a capital dos imperadores-soldados está onde eles permaneciam, isto é, onde eles podiam deter do melhor modo às ameaças bárbaras. Essas residências imperiais, oriundas da crise, estendem-se de oeste a leste: Tréveris, Milão, Aquiléia, Sírmio, Naissus, Sérdica, Tessalônica, Nicomédia. Uma característica comum a todas: é que se localizam na linha das vias de comunicação que ligam a embocadura do Reno ao mar Negro e à Ásia Menor. O próprio Constantino deslocou-se segundo as etapas da sua reunificação do Império.

Roma não é mais conveniente devido a vários fatores: está localizada em um ponto muito afastado das frentes do império ameaçado; é vulneravel ao ataque dos bárbaros vindos da Germânia ou da Ilíria .

A excelente localização de Roma (na encruzilhada da rota qu liga a Etrúria com a Campânia e a via do Tibre ligando o mar com o interior da península) o é em relação à Itália e não em relação ao império. Sua posição, no centro do Mediterrâneo, na junção da bacia ocidental e da oriental, no triângulo do mar Tirreno (costa italiana, Si-

(10). - F. Lot. Apud Rémondon, op. cit., p. 198.

(11). - Vasiliev, Piganiol. Apud Rémondon, loc. cit.

(12). - P. Lemerle. Apud Rémondon, loc. cit.

(13). - Ibidem. 
cília, ponta da África, Sardenha e Córsega) onde se encontram o leste e o oeste, a África e a Europa, perdeu parte de sua importância desde que o eixo do Mediterrâneo decaiu. Roma não era capaz de reanimar este eixo; seu vigor econômico não era suficiente. A vida literária abandonou-a: a literatura de língua latina tornara-se africana.

Roma era capital apenas graças ao peso do passado.

Quanto ao problema do cristianismo, Roma não é nessa época uma cidadela do paganismo - pretender que Constantino deixou-a porque era pagã, torna inexplicavel a obstinação dos papas em manterem-se nela.

Roma fora a capital porque os dois mandatários mediante os quais o povo exercia seus direitos ilimitados de soberania eram o imperador e o senado de Roma.

Embora sua aristocracia fosse ainda uma força social e política, o senado, como orgão, já não dispõe de poder político. Os exércitos ou a herança dinástica criam os imperadores, e não mais o senado ou o povo.

A ausência constante dos imperadores de Roma contribuira para aniquilar definitivamente a instituição do senado. Havia graves e justificadas razões aconselhando a proximidade dos supremos comandantes do exército junto às fronteiras; portanto a residência das cortes na época da tetrarquia tornou-se posto avançado. Constâncio Cloro residia habitualmente em Tréveris, nos confins do Reno; Galério em Sírmio, no Danúbio; Maximiano instalou-se em Mediolanum e Diocleciano na Nicomédia da Bitínia, cidade que se localizava a igual distância entre o Danúbio e o Eufrates. Essas capitais da tetrarquia eram ainda sede de numerosos exércitos de reserva, lembrando mais campos militares que pacíficas cidades. Em consequência desta situação todos os negócios públicos eram tratados nas quatro novas residências dos funcionários de cada corte e não havia sequer a possibilidade material de consultar o senado. As faculdades do mesmo foram delegadas, acrescendo-se os encargos dos funcionários, acarretando a formação de uma burocracia cada vez mais numerosa. Com o objetivo de afastar o perigo das usurpações tão comuns durante o século III, adotaram-se medidas que diminuiam o poder dos funcionários mais altos e implicitamente mais perigosos.

Não existiam mais razões políticas para o imperador residir em Roma, enquanto que as necessidades de defesa e de manutenção da unidade do império exigiam que ela fosse abandonada. Por que não criar então uma Nova Roma?

Por que funda-la em Bizâncio? A escolha do sítio justifica-se pela importância estratégica e econômica dos Estreitos. 
Em decorrência das invasões do século III, a defesa do império exigia que a capital estivesse situada nas proximidades da grande via estratégica que partindo do mar do Norte, remonta o Reno, percorre as províncias danubianas e a Itália do Norte, comunicando-se por um lado com o Danúbio e por outro com Milão, Verona e Aquiléia; descendo pelo vale do Drava, segue o Danúbio e em seguida, pelos vales do Morava e do Mariza, alcança o Bósforo. Prolonga-se mais alem, através da Ásia Menor, até a Cilícia e Antioquia: constitui-se no ponto de saida para as províncias mais meridionais do Império ou para a frentc persa. A capital não deveria ocupar um lugar excêntrico nesta via.

Nas condições da economia antiga a construção de uma cidade elevada à categoria de capital devia levar em consideração o seu desenvolvimento econômico e demográfico, bem como o seu abastecimento. Tal cidade não deveria ficar longe das rotas de abastecimento, ou seja, do mar.

$\mathrm{Na}$ grande diagonal terrestre imposta pelas necessidades de defesa, o ponto mais favoravel para a instalação de nova capital era aquele em que essa diagonal cruzava-se com a rota marítima Mediterrâneomar Negro. Neste ponto localizam-se os Estreitos. A ele tem facil acesso, po: via marítima ou terrestre, os produtos manufaturados das cidades da Ásia Menor e da Síria; através do mar, o trigo do Egito garantia o abastecimento. Segundo Rémondon, este último aspecto teve influência decisiva na escolha do sítio urbano da nova capital (14).

Constantinopla situava-se suficientemente longe do Danúbio a fim de evitar ataques de surpresa, mas convenientemente próxima para permitir pronto revide a eventual agressão. Neste período o baixo Danúbio constituia-se no setor mais ameaçado das fronteiras. Instalado em Constantinopla, o imperador teria condições de vigiar a fronteira do baixo Danúbio e ao mesmo tempo o inimigo persa.

Constantinopla seria o baluarte do helenismo contra os bárbaros. Na praça do Stratégion Alexandre passara em revista suas tropas antes de partir para a conquista da Ásia; próximo à estátua de Alexandre, Constantino faz erigir a sua, como desejando imitar o o exemplo.

Constantinopla destinava-se a transformar-se em grande centro comercial. Políbio já admirava sua incomparavel localização. Contudo Eunápio observava que os barcos não podiam penetrar no porto

(14). - Rémondon, op. cit., p. 201. 
senão com o vento sul (15). Esta afirmação é verdadeira apenas no que se refere ao Corno de Ouro; a cidade dispunha de outros ancoradouros.

A grande via que ligava as novas capitais, Tréveris, Milão, Sírmio, e que em Constantinopla atinge o mar, dirigindo-se para a Ásia, constituia-se na rota percorrida por todos os imperadores com seus exércitos. Transformara-se tambem em caminho de peregrinações: um devoto anônimo que dirigindo-se de Bordeos a Jerusalem em 333 deixou-nos o seu itinerário, passou por Constantinopla .

A proximidade dos centros intelectuais da Grécia( Tessalônica, Atenas), da Āsia Menor (Nicomédia, Nicéia, Pérgamo, Efeso), da Síria (Antioquia, Beirute, Cesaréia), do Egito (Alexandria), facilitava o desenvolvimento da cidade, fornecendo-lhe uma reserva de funcionários aptos a preencher os cargos oferecidos por uma crescente burocratização do império.

Constantino decidiu-se fundar uma nova capital a partir de novembro de 324, pouco após suas vitórias de julho e setembro contra Licínio em Andrinópolis e Crisópolis. Iniciados imediatamente, os trabalhos de construção duraram até 336 . A consagração da cidade contudo efetuou-se a 11 de maio de 330 .

A fundação de um edifício ou de uma cidade exigia, entre os pagãos, uma dupla cerimônia: de início, a consagração do terreno e posteriormente a dos monumentos. Constituia-se num rito religioso; espíritos eram exorcisados e outros invocados. Constantino respeitou estes ritos. A consagração do terreno foi efetuada a 8 de novembro de 324 e a dos monumentos a 11 de maio de 330 , presidida pelo filósofo neoplatônico Sôpatros. Procedeu-se a um sacrifício dedicado à Tyché da cidade e um sacrifício não sangrento ao verdadeiro Deus. Como parte essencial dos ritos figuravam os jogos; era costume que as corridas fossem precedidas por procissões de estátuas dos deuses, as quais realizavam volta em torno da arena, antes de se deterem num altar situado no camarote imperial. Segundo a vontade do imperador foi decidido que sua estátua figuraria, juntamente com a da Tyché da cidade, na procissão comemorativa anual; seria seguida por soldados portando círios, sendo depositada defronte ao camarote imperial.

Pelas suas características a cidade pouco se assemelhava a uma capital cristã. Os antigos templos foram respeitados; diariamente os Dióscuros eram venerados no hipódromo; novos templos foram edificados para a Tyché de Roma e para a Grande Mãe. Na coluna do

(15). - Eunápio, Vie d'Aedesius. Apud Piganiol, A., L'empire Chrétien (325-395). Paris, Presses Universitaires de France, 1947. Tomo IV, $2^{\circ}$ parte da "Histoire Romaine" da Coleção Glotz, p. 50. 
novo Forum foi erguida uma estátua dedicada a Constantino-Sol. Os templos consagrados à Sabedoria, à Paz, eram apropriados a uma capital da filosofia, uma Plotinópolis.

Anteriormente a Constantino, Bizâncio era administrada por uma boulé, a qual elegia um arconte. Dependia do praeses que de sua capital, Heracléia, governava a pequena província européia, dependendo também do vigário da Trácia.

Constantino transformou-a na réplica oriental de Roma. Transformou a boulé em senado, no qual incluiu as grandes personalidades; todavia, estas recebem apenas o tratamento de clari, reservando-se o título de clarissimos aos senadores de Roma. O arconte assumiu o título de proconsul. Portanto Constantinopla cessou de depender do governador da Europa e do vigário da Trácia. O jus italicum lhe foi conferido, tornando seu território isento de imposto. A distribuição de trigo ans cidadãos de Roma era, em princípio, não uma medida assistencial, mas de certa forma, a consagração de direitos dos vencedores do mundo. Privilégio análogo foi concedido por Constantino à nova capital. $\mathrm{O}$ direito à distribuição de trigo estava ligado à posse de uma casa; o imperador estendeu o privilégio a alguns corpos de sua guarda. Em 324 foi aberta casa de cunhagem para a qual foram transferidos os artesãos de Aquiléia.

Em 330 a corte e as secretarias instalaram-se nela; a primeira lei datada de Constantinopla é de 16 de julho. O imperador Constantino aí residıu quase continuamente até a morte. O seu túmulo foi preparado numa das igrejas por ele construida, a dos Apóstolos.

Constantino, espírito pouco helênico por natureza e por formação cultural, não imaginava que a fundação da cidade reergueria o helenismo contra a romanidade. Alem de trazer grande número de ocidentais, a língua oficial da corte e da administração permaneceu sendo o latim. Equivocou-se contudo ao calcular que a cidade permaneceria um centro de cultura latina. Decorrido algum tempo, os imigrantes ocidentais ou seus descendentes haviam esquecido o latim em favor do grego e a Nova Roma tornava-se política, religiosa e culturalmente a decidida antagonista da Velha Roma. Constantinopla seria região grega pela língua corrente, pela geografia e pela história; o próprio nome era sugestivamente grego. O helenismo nela encontrou sua capital, enquanto que Roma consequentemente transformava-se na capital do romanismo.

Esta espécie de desdobramento foi de molde a apressar a divisăo do império em duas partes. O longo prazo, preparava tambem a divisão da cristandade em uma Igreja do Ocidente e uma Igreja do Oriente. Quanto ao cristianismo, o fato do imperador afastar-se de Ro- 
ma teve como efeito facilitar o aumento da influência do bispo de Roma, assegurando-lhe maior liberdade de ação.

Criando uma segunda capital, politicamente quase igual à antiga Roma (16) e fundando-a no Oriente, Constantino aumentou a distinção entre as duas partes do Império. Serão reforçadas as diferenças de ordem política (densidade e tipo de urbanização), econômica( atividade industrial, distribuição de riquezas), social (estruturas agrárias), linguística e cultural (civilização latina no oeste e grega no leste), religiosa (poder desigual do cristianismo e do paganismo, bem como diferentes mentalidades religiosas ) (17).

As diferenças traduziam-se em vantagens para o Oriente. $O$ impulso que a fundação da nova capital the deu, aumentou a superioridade oriental. Ao fundar Constantinopla, o imperador preparou o nascimento do Império Bizantino e a sobrevivência da civilização grecolatina (18).

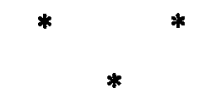

CONCLUSÃO.

E possivel delinear toda uma galeria de retratos de Constantino, tão diferentes que chega a ser dificil acreditar tratar-se do mesmo personagem.

Eis inicialmente a imagem piedosa inspirada na "Vida" atribuida a Eusébio. Constantino teve uma visão de Cristo em 312 e esta o converteu; preocupado sobretudo com sua salvação e com a salvação de seu povo, deseja reformar os costumes e preparar o triunfo do verdadeiro Deus. Proclamando-se cristão, rompeu com a tradição de Roma, tornando possivel o advento de uma nova sociedade; ele se considera um bispo, talvez mesmo o décimo-terceiro apóstolo.

Juliano esboça evidentemente um retrato bastante diferente em seu panfleto sobre os Césares; o quadro apresentado é bem mais sombrio.

Foderíamos passar em seguida à imagem que nos apresenta um homem de Estado dotado de implacavel realismo, incapaz de tomar

(16). - A Antiga Roma não perdeu nenhum de seus privilégios; Constantinopla, a Nova Roma, era-lhe inferior. Não possuia prefeito da cidade, apenas proconsul; seus senadores recebiam apenas o título de clari. Cf. Rémondon, op. cit., p. 200.

(17). - Ibidem, p. 70 .

(18). - Ibidem. 
decisões por motivos sentimentais, agindo movido apenas por motivos relevantes.

Todos estes retratos tão diferentes contem seguramente traços verdadeiros. O único que parece menos exato é o de homem de Estado realista. Para realizar sua grande obra Constantino precisava ser um inspirado. Ele permitiu que forças novas se desencadeassem pela primeira vez abertamente. Deveria ter agido mais energicamente: em lugar de sonhar que era um apóstolo teria sido mais proveitoso que houvesse ido combater o inimigo no Danúbio. Mas sua política religiosa, por mais discutivel que seja, foi bastante superior às concepções mesquinhas de um Atanásio. Toda a evolução do paganismo tendia a assegurar o culto do grande Deus de Platão. Constantino acreditou encontrar no cristianismo a mais alta expressão desse culto, capaz de conseguir a adesão dos próprios filósofos. O império achava-se minado pela defecção das massas cristãs. Instalar o cristianismo no trono foi um traço de gênio; não podemos acusar Constantino pelo fato do cristianismo ter-se recusado a unir sinceramente sua causa à da pátria romana.

A dinastia era apoiada, de um lado, pela dedicação do exército, de outro, pela religião. Constantino compreendeu que a religião era a única sanção concebivel do poder despótico. Embora todos os seus predecessores, a partir de Augusto, tivessem percebido isso, o culto do imperador intruduzido na era augustana transformou-se, após a morte daquele imperador, numa simples instituição estatal, em nada ligada à religião. O principado de Augusto e seus sucessores imediatos assim como o principado dos Antoninos não tiveram sanção religiosa: baseavam-se na ligação do princeps com o Senado e o povo romano no fato de que o princeps era o representante legal de ambos. No século III essa ligação desapareceu e foi portanto natural que os imperadores dessa época procurassem aproximar sua autoridade da mais poderosa corrente religiosa de então - a que prevalecia entre os soldados. Eram muitas, porem, e nenhuma delas se impunha sobre as outras de modo irrecusavel. Por isso, Heliogábalo e Aureliano, apesar de todos os seus esforços, não conseguiram estabelecer uma religião oficial.

Constantino compreendeu melhor a situação e renovou a tentativa de criar uma única religião estatal, obtendo dela o apôio à autoridade imperial. Sua tentativa teve êxito. O simples fato de que se tivesse criado um poder despótico e hereditário, intimamente ligado à religião do Estado e dela inseparavel, prova uma coisa - que o velho Estado romano, formado pelo Senado e pelo povo de Roma deixou de existir no reinado de Constantino, sendo substituido por um novo sistema que deveria governar tanto o Oriente como o Ocidente por muitos séculos - a monarquia pela graça de Deus. A mesma época viu 
a morte de outra idéia fundamental da civilização greco-romana - o ideal de cidadania e liberdade. Na monarquia que se seguiu a Constantino já não havia lugar para os cidadãos das cidades-Estado da Grécia e Itália: em seu lugar estavam os súditos.

Os últimos vestígios do sistema de Diocleciano tombaram e a monarquia hereditária podia finalmente governar todo o império, cuja unidade fora reconstituida. A longa evolução da grande República aristocrática, reorganizada por Augusto, chegava ao seu termo. Constantino teve a capacidade de criar a dinastia que governaria o vasto império cono os Ptolomeus governaram o Egito. Existiam muitas condições favoráveis ao sucesso. A repugnância do espírito e da tradição greco-latina estava morta. Não havia mais instituições suficientemente fortes para opor uma resistência séria. O Império necessitava de uma autoridade central, única, forte, permanente, capaz de substituir, juntamente com a burocracia dela dependente, a aristocracia desaparecida.

Constantino foi acusado de haver "traido Roma"; ao menos ele aplicou o golpe mortal na tradição romana, respeitada por Diocleciano, contribuindo fortemente, sem esquecermos a fundação de Constantinopla, para o advento do Estado Bizantino.

Se o julgarmos do ponto de vista de Roma, seu débito é pesado. Contribuiu para o fortalecimento da nascente servidão nas grandes propriedades. Queimou livros de filósofos. Concedeu a generais germânicos as maiores honras de Estado. Se o julgarmos do ponto de vista da Iảade Média, é preciso reconhecer que ele nos oferece a primeira imagem do soberano medieval, vivendo com os olhos voltados para o céu.

\section{BIBLIOGRAFIA}

ALBERTINI (Eugène). - L'empire romain. 2. ed. Paris, Félix Alcan, 1936. BLOCH (Raymond) e COUSIN (Jean). - Roma e seu destino. Tradução de Maria Antonieta Magalhães Godinho. Lisboa, Cosmos, 1964.

FERRERO (Guglielmo). - La ruine de la civilisation antique. Paris, Plon. HOMO (Léon). - L'empire romain. Paris, Payot, 1925.

HOMO (Léon). - Les empereurs romains et le christianisme. Paris, Payot, 1931.

JONES (A.H.M.). - "A última crise: o império romano até seu declínio". in: BALDON (J.P.V.D.), org. - O mundo romano. Rio de Janeiro, Zahar, 1968. 
LOT (Ferdinand). - La fin du monde antique et le début du moyen âge. La Rennaissance du livre, 1927.

PALANQUE (Jean-Remy). - Constantino. Tradução de Manuel Salvaterra. Rio de Janeiro, Atlântica Editora.

PARIBENI (Roberto). - Da Diocleziano alla caduta dell'Impero d'Occidente. Bologna, Licinio Cappelli, 1941.

PETIT (Paul). - História antiga. Tradução de Pedro Moacyr Campos. São Paulo, Difusão Européia do Livro, 1964.

PIGANIOL (André). - L'empire chrétien. (325-395). Paris, Presses Universitaires de France, 1947. Tomo IV, $2^{\circ}$ parte da "Histoire Romaine" da Coleção Glotz.

REMONDON (Roger). - La crisis del Imperio Romano de Marco Aurelio a Anastacio. Barcelona, Labor, 1967.

ROSTOVTZEFF (Michel). - História de Roma. 2. ed. Tradução de Waltensir Dutra. Rio de Janeiro, Zahar.

ROSTVTZEFF (Michel). - Historia social y económica del Imperio Romano. Tradução do inglês por Luis López-Ballesteros. Madrid, EspasaCalpe, 1937. Tomo II. 